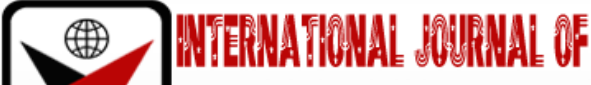

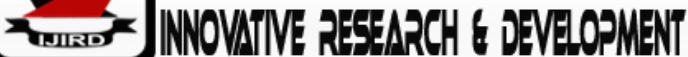

ISSN 2278-0211 (Online)

\section{Legal Capacity of Non-COVID Patients in Human Rights Enforcement in Indonesia}

\author{
Dr. Muhammad Natsir \\ Lecturer, Department of Law, Amsir Law College, Indonesia
}

\begin{abstract}
:
The Covid-19 pandemic has brought many changes in people's living order in Indonesia. In this case, the health sector and hospitals as facilities and infrastructure of health facilities organizers have many challenges so as not to become the main victims in the spread of this pandemic. However, one of the less fortunate cases was the death of pregnant women due to the hospital's negligence in handling the first childbirth during the Covid-19 pandemic. This study aims to further examine the extent to which it is regulated in the legal system in Indonesia, the main responsible strategies and institutions, as well as other aspects that can be found in the confusion of the problem. Researchers used the GoalFree Evaluation Framework as an independent form of the goals to be achieved in the Human Rights Act and looked at the other side to be found during the evaluation of the issue of Human Rights violations. The result is that human rights have been regulated from the acceptance of health services by the public and employment laws of the medical team and hospital strategies listed in the Service Operational Standards but have not been fully implemented. Furthermore, it is the responsibility of the local government in minimizing the occurrence of human rights violations as the institution that is most attached to the community despite the national Human Rights Commission in charge of further reviewing the issue, especially after the findings are found and other factors arising from the case.
\end{abstract}

Keywords: Capacity, Covid19, human rights

\section{Introduction}

Covid-19 cases have spread in Indonesia since 2019 and almost reached 128,776 cases on August 11, 2020. (GlisinaDwinoorRembulan and others, 2020), Not only in Java Island covid-19 cases spread almost evenly throughout the provinces in the archipelago, with major cities such as DKI Jakarta, West Java, East Java, and Central Java still winning the highest cases. (https://nasional.kompas.com/read/2020/12/16/15053601/4-provinsi-ini-alami-kenaikan-tertinggikasus-covid-19-usai-libur-panjang. Accessed 1 June 2021). Based on world meter data in 2020 the total deaths have reached 19,390 people with the number confirmed positive is 643,508 people (PutuAndaTustaAdiputra, 2020: 29). In the course of the Covid-19 pandemic, the Indonesian government experienced many major challenges in terms of health facilities and medical teams as the vanguard of Covid-19 response. The challenge is very related to the main problems found in the health sector in Indonesia such as hospital capacity, standards of facilities and facilities and facilities, and mental and physical health by the medical team itself. This is as stated by dr. NurHidayah in his presentation that expressed some facts that will happen if the hospital is not agile in mitigating pandemics, namely the first source of infection transmission for medical personnel and nosocomial for the families of patients who will eventually be unable to carry out their toxicology as a provider of health facilities as it should be. (NurHidayah, 2020)

This challenge is further addressed in such a way as not to be a failure in the treatment of Covid patients let alone as an opportunity to increase the number of cases in Indonesia. Some of the strategies carried out by hospitals include. (Glisina Dwinoor Rembulan and others, 2020) conducting strict supervision and control of each hospital in Indonesia, guarantee the fulfillment of medical personnel in the handling of patients in each region, improve fakes, ensure the availability of medical protective equipment (PPE) for the medical team, the handling of emergency patients more responsive according to health standards, and self-isolation for suspect Covid-19 mainly from the medical team itself. This is as stipulated in the regulations that prepare hospitals as the vanguard, among others. (NurHidayah, 2020). Presidential Decree No. 11 of 2020 concerning the Determination of Public Health Emergency Corona Virus Disease (Covid-19), Presidential Decree No. 12 of 2020 on The Determination of Non-Natural Disasters Spreading Covid-19 as a National Disaster, Regulation of the Minister of Health No. 9 of 2020 concerning Guidelines for Large-Scale Social Restrictions to Accelerate Handling of Covid-19, Guidelines for Prevention \& Control of Covid-19.

In addition, hospitals are required to carry out strict procedures to ensure the cleanliness of health facilities and high utilization of technology in avoiding human error by medical personnel, as the mandatory guidelines provided by the Centers for Disease Control \& Prevention (CDC) isolation of patients with the use of surgical health facilities to the placement of patients in the infection isolation room (Airborne Infection Isolation Room) that must be applied by the hospital. But behind the implementation of strict Covid-19 handling procedures, there is another side that makes it 
difficult for people to get ease in receiving hospital services. These cases are rampant such as the individualization of noncovid patients and services that ignore non-covid patients as reported on Kompas.com one of the cases that occurred in South Sulawesi a pregnant woman was rejected as many as seven hospitals to perform childbirth for several reasons such as the unavailability of rapid tests and the unavailability of intensive care unit so that after arriving at the eighth hospital a.nHartina died. (https://properti.kompas.com/read/2020/03/06/200000621/hadapi-virus-corona-ini-6-langkah-yangwajib-dilakukan-rumah-sakit?page=all. Accessed 11 June 2021)

This was not because of a deliberate thing Hartina had previously intended to carry out childbirth in Integrated Healthcare Center or at home but suddenly Hartina's condition convulsed and needed a medical team but, in the end, was rejected even though the family had pleaded with the local hospital. Some of these hospitals are from Bontobangun Bulukumba Health Center and then referred to Bantaeng Regional General Hospital, then taken to LabuangBaji Makassar Hospital, Kartini Hospital, Ananda Hospital, Plamonia Hospital and finally breathed the last breath at Wahidin Sudiro Husodo Hospital. Another case of pregnant women who also want to have surgery due to breach fetus but suspected reactive to Covid-19 resulted in the patient being rejected by the hospital due to the absence of an isolation room. (https://www.indozone.id/news/WYsvz6D/kondisi-bayi-sungsang-ibu-hamil-ditolak-rumah-sakit-karena-reaktif-covid19-ini-akhirnya/read-all. Accessed 11 June 2021)

A similar case occurred in Singkawang, West Kalimantan, where an asthmatic patient was put in isolation and not in an Intensive Care Unit room like a Covid-19 patient. The family is not allowed to see the patient, the patient is placed in a closed room with his feet and hands tied. The family did not accept and asked for the patient to be taken home but the hospital instead made a requirement that the patient will not be covered by BPJS so that the patient must pay 2.5 million rupiahs for the hospital fee. Worse still to avoid negative news, the hospital spread the news that the patient refused to be swab so that three days later officers and authorities forcibly picked up and performed a swab even though the patient's condition had deteriorated. Swab results showed negative but in the end patients who could not be treated properly died after attempting to borrow hospital oxygen tubes but were not given unless they provided a security deposit of 1.7 million rupiahs. (https://regional.kompas.com/read/2020/12/15/16555921/kasus-rumah-sakit-anggap-pasien-positif-covid19-ganjar-laporkan-ke-saya?page=all>. Accessed 11 June 2021).

Meanwhile, in Semarang, Central Java, one of the families of patients who were accused by the Hospital in Kebumen was exposed to Covid-19 and buried as a covid-19 procedure but after further investigation, the patient only suffered from asthma and died from the disease. (https://nasional.kompas.com/read/2020/10/05/15350241/saatrumah-sakit-dituding-mengcovid-kan-pasien?page=all>.Accessed 21 June 2021).

The case was also emphasized by the governor of Central Java Ganjar Pranomo as cited by Kompas.com. 'There are people estimated covid-19 continues to die, even though the test results have not come out. After the results came out it turned out to be negative. It's a pity, these are examples of us fixing this.'

Similarly, the Staff of the President of the Republic of Indonesia Moeldoko said that some cases such as abuse of civic-19 status have been found such as accident victims or patients with ordinary illness (non-covid) mentioned death due to Covid-19 by the hospital but the facts are different 'This needs to be straightened out so as not to benefit those who want to profit from the definition'

In contrast to the case that occurred in Balikpapan reported from the online media www.indozone.id that revealed that a non-covid 19 patient was ignored in receiving hospital services. Some hospitals in Balikpapan refuse to accept patients and prioritize Covid-19 patients and ignore a patient with complications of the disease so that the patient dies. (https://www.indozone.id/news/jzsQd5p/ditolak-3-rumah-sakit-karena-bukan-covid-19-wanita-ini-saksikansakratul-maut-sang-ayah/read-all>.Accessed 21 June 2021).

There are three hospitals in Balikpapan that reject the victims, among others as quoted from the news are Dr. $\mathrm{R}$ Hardjanto Hospital, Gunung Malang Regional General Hospital, and Pertamina Hospital, the reason is that the Intensive Care Unit room is full of Covid-19 patients so it cannot handle other patients. This violates the human rights law listed in article $28 \mathrm{H}$ paragraph (1) which reads that 'everyone has the right to live a prosperous life born inwardly, reside and get a healthy environment and entitled to health services'. Then another article is 34 paragraph (3) which states that 'the state is responsible for the provision of health care facilities and public service facilities that are' (JendriMaliangga. 2013: 5). Therefore, this study aims to further examine how this problem has been regulated and processed in the legal system in Indonesia as well as the strategies and institutions in charge of the main and other sides that can be found in the confusion of this problem. The method used by library studies outlined in descriptive research using the Goal Free Evaluation Framework as an independent form of the goals to be achieved in the Human Rights Act and to see the other side that will be found during evaluating the problem of human rights violations during the Covid-19 pandemic.

\section{Research of Method}

This study aims to further examine the extent to which this is regulated in the legal system in Indonesia, the strategies and institutions in charge of the main, and other sides that can be found in the confusion of this problem. Therefore, researchers use the Goal Free Evaluation Framework as an independent form of the goals to be achieved in the Human Rights Act and to see the other side that will be found during evaluating the issue of human rights violations. The result is that human rights have been regulated from the acceptance of health services by the public and employment laws of the medical team and hospital strategy listed in the Service Operational Standards but have not been fully implemented.

\section{Research Result and Discussion}

Since the Covid-19 pandemic occurred in Indonesia health care facilities have minimized the provision of health services for general patients or Non-Covid-19 to focus more on handling pandemics as well as internal protection to avoid 
transmission to health facilities services (Kemenkes, 2020). However, in practice some cases it is found that the hospital deliberately categorizes non-Covid-19 patients as patients with Covid-19. This is without reason, based on the Letter of the Minister of Finance Number S-275/MK 02/ 2020 since April 3, 2020, concerning Reimbursement Unit for The Cost of Care of Certain Emerging Infectious Disease Patients for Hospitals that hold Coronavirus Disease 2019 (Covid-19) services with a minimum tariff rule of 105 million rupiahs and a maximum tariff of 231 million rupiahs per individual. Some issues then arise related to this regulation both positive and negative where the issue of the emergence of mafia or irresponsible parties who want to take a chance by blacking out non-Covid 19 patients and negative views of people who are reluctant to visit the hospital unless in an emergency. (https://nasional.kompas.com/read/2020/10/05/15350241/saat-rumah-sakitdituding-meng-covid-kan-pasien?page=3>. Accessed 21 June 2021)

\subsection{Governing Regulations}

\subsubsection{Service Operating Standards}

The number of cases that occur such as the rejection of Non-Covid 19 patients turn out to be a form of reaction from medical teams and health workers in anticipation of avoiding hospitals as the most vulnerable places in the spread of Covid-19. Some problems arose that resulted in death for the medical team. Based on data from the General Manager of the Indonesian Doctors Association (PB-IDI) the total number of medical personnel who died from Covid-19 during the treatment of patients was 363 people. Therefore, the Ministry of Health of the Republic of Indonesia issued a reference book for hospitals in Indonesia to divide the service system into two, namely Covid-19 and Non-Covid 19 patients. (https://www.msn.com/id-id/berita/other/363-tenaga-medis-meninggal-karena-covid-19-ini-3-saran-dari-idi/ar-

BB1bXoni>. Accessed 26 June 2021)

As stated in the Technical Guide of Hospital Services by the Ministry of Health during the adaptation of new habits, the Service Flow Arrangement will be divided into three parts, namely patient flow, screening, and triage. Meanwhile, the zone will be divided into the Covid-19 zone and non-Covid-19 zone. This aims to implement the principle of new adaptation to continue to run public patient services by minimizing the spread of the Covid-19 virus or the so-called balancing act. In general, the system will be run more strictly such as screening, visit schedule, patient admission, visitor restrictions, and separation of services for Covid-19 and non-Covid 19 patients.

However, the shortcomings that occur are that emergency patients will be more difficult to get non-Covid 19 services because in the screening scheme it takes longer in checking patients affected by the Covid-19 virus or not. If from the results of screening (at your request and without agreement) the patient is obtained to suffer from Covid-19 then the patient is addressed to the triage of Emergency Installation or special outpatient Covid-19. Furthermore, if there are no results of patients suffering from Covid-19 then otherwise the patient will be transferred to the same room class and the same outpatient but with the non-Covid19 scheme following what is needed by the patient. As a result of screening takes longer and is vulnerable for emergency patients, the triage scheme is also run by hospitals. Triage is principled in patients who need immediate medical treatment and performed at the entrance of the Emergency installation and outpatient which will then be conducted to control the degree of Covid-19 infection through a complete examination. However, the fully running screening and triage system will be hampered if the isolation room is not available, the slow transfer of patients in the triage room to LOS in the Emergency Installation with the yellow triage average is above 6 hours (FirdausKristyawan and RinikEkoKapti, 2020: 14) and inadequate Intensive Care Unit services. (http://zonamahasiswa.id/insiden-rumah-sakit-tolak-pasien-hingga-bayinya-meninggal-sobat-zona-pantaskah-nilaikemanusiaan-diganti-dengan-uang/. Accessed 30 Juni 2021).

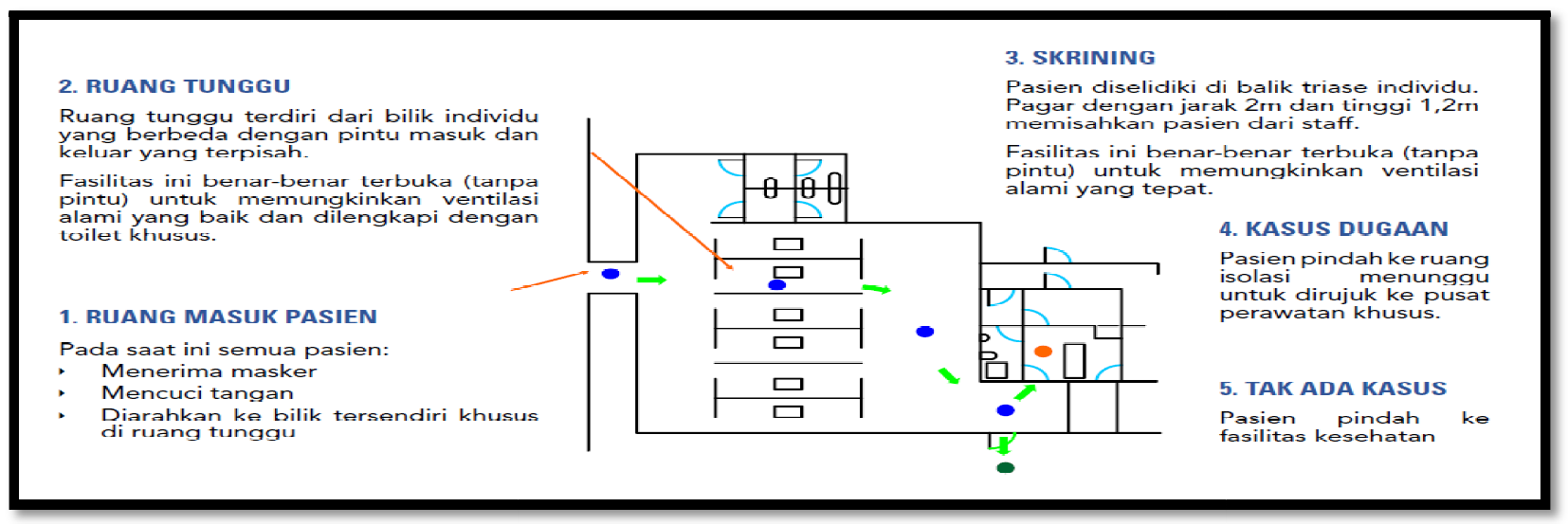

Figure 1: Hospital Admission Screening Scheme

Source: Ministry of Health, Republic of Indonesia, 2020

\subsubsection{Human Rights Act and Employment Law}

Basically, this issue has been regulated in the efforts to protect human rights for the community in this case the patient has been regulated in such a way in the system of legislation in Indonesia. Based on Law No. 36 of 2009 on health as stipulated in articles 4 to 8 as a form of positive law that will apply in each region in Indonesia, 'Human rights in the field of health services for everyone, namely: 
- Equal rights in gaining access to health resources

- The right to obtain safe, quality, and affordable health services

- The right independently and responsibly determines for itself the health services necessary for itself

- The right to a healthy environment for the achievement of health degrees

- The right to information and education about balanced and responsible health

- The right to obtain information about his health data including actions and treatments that he has or will receive from health workers'

Therefore, if the leader of a health facility or medical personnel deliberately does not provide first aid or rejection to patients in an emergency and causes death is a form of reduction in the fulfillment of human rights that has been stipulated in article 36 of 2009 on health. (Irwansyah Reza Mohamad, 2019: 26).

In addition, article 47 of Law No. 36 of 2009 states that 'Health efforts are organized in the form of activities with a promotive, preventive, curative and rehabilitative approach that is implemented in an integrated, comprehensive and sustainable manner' and in this case, if the hospital refuses intentionally it will violate curative health services or in the sense of medical activities that have the purpose to cure diseases, reduce patient suffering due to disease, disease control, and disability control. Legal protection for patients is also based on the patient in receiving the first service following the ability of the hospital in applying health sciences and technology as well as the right of the patient as an individual in determining his fate or so-called as 'the right to self-determination'. (Glisina Dwinoor Rembulan and others, 2020) Furthermore, one of the most common forms of legal protection used today to patients is the protection of patients by providing compensation provided both formally and material by hospitals. (Glisina Dwinoor Rembulan and others, 2020) If negligence resulting in harm to patients but still reaping the pros and cons due to the issue of humanity imbalance replaced with the material in the form of money.

In addition, the System of Legislation in Indonesia also regulates the human rights of medical personnel in the legislation in Indonesia, among others, Law No. 36 of 2009 on health, Law No. 44 of 2009 on Hospitals and Law No. 36 of 2014 on health workers and other health law products. One of the labor laws that regulate the main issue of technical protection of health workers to be protected from accidents that can be caused or known as work safety, namely, Law No. 13 of 2003. These two systems of legislation govern two different aspects of humanity. The general public is entitled to health care. Meanwhile, legal and occupational safety protection to avoid Covid-19 needs to be implemented to protect medical teams and health facilities as the center of Covid-19 treatment and treatment facilities and infrastructure in all regions in Indonesia.

Furthermore, although human rights have been regulated in such a way in the legal system in Indonesia the implementation process in the enforcement of human rights is difficult to implement mainly from health care providers. For example, in the case that occurred in Suhartina some hospitals that received victims did not run the standard of service operations as stipulated this is not without reason but because the technical guidelines of hospital services have only been in place since November or the end of 2020 where the covid-19 pandemic period has been running for almost a year, the unpreparedness of hospitals in receiving emergency patients due to the lack of Intensive Care Unit services so that hospitals rejected received patients because patients with a condition of decreased consciousness and deep breathing in need of more qualified intensive care but after being transferred to several hospitals with similar rejection Hartina eventually died.

This is further incompatible with the legal curative protection guidelines for patients where the patient is entitled to receive examination and treatment with available technology to reduce the suffering of patients due to disease or in this case childbirth faced by Hartina. Therefore, it can be said that the application of medical services in some regional hospitals in Indonesia has not implemented the Standard of Service Operations on Indonesian positive law means following the rights and obligations that have been stipulated in the laws and regulations.

\subsection{The Role of Government and Law Enforcement and Responsible Strategies and Institutions}

\subsubsection{Institution in Charge of Human Rights}

In the framework of human rights enforcement can be reached through legal channels and political channels. This is with the aim that if human rights violations are found, every effort is made to crack down legally on human rights violators. But in fact, the analysis of problems, assessment, and a crackdown on human rights violators is difficult to carry out in Indonesia. So that the presence of the National Commission on Human Rights is expected to be able to help human rights violations, especially those that occur during the Covid-19 pandemic that is very much found related to the rejection of emergency patients or even vice versa deliberately Covidien non-covid-19 patients that cause social unrest and social effects in life in the community. Therefore, to protect the legal rights of patients with Covid-19, it is stated in article 32 letter i of Law No. 44 of 2009 concerning hospitals. This article regulates the right of patients and the obligation of hospitals to keep in secret medical secrets and records of health media. It is very important during the Covid-19 pandemic for hospitals to comply with this article to avoid unrest and negative effects that occur in social life in the community (Rahandy Rizky Prananda, 2020: 68),

However, the fact that legal protections provided for medical record data by patients has not been comprehensively implemented in contrast to countries in Europe that carry out the principle of proportionality, necessary and purposive limitation in managing medical record data which means patient data is only used in certain conditions and essential needs.

The National Commission on Human Rights as an independent institution and fully authorized as stipulated in article 28 I paragraph 4 of the Constitution of the Republic of Indonesia of 1945 which affirms that' the protection, 
promotion, enforcement and fulfillment of human rights is the responsibility of the government', and the Decree of the People's Consultative Assembly Number VXII/MPR-RI/1999 on Human Rights which is another task of the Human Rights Commission is to review, examine, monitor, monitor and mediate. (Laurensius Arliman S, 2017: 54)

The following is the purpose of the establishment of the Human Rights Commission in upholding Human Rights in Indonesia: developing situations and conditions conducive to the implementation of human rights and improving the quality of protection and enforcement of human rights. But it is necessary to be aware in general cases that it will be difficult to fight if the hospital refuses emergency patients this is because of the position of the hospital that is also required to follow the Standard of Service Operation in the form of screening and triage. However, if the hospital deliberately refuses without making any prior efforts with the operational personnel and technology available the patient's family reserves the right to prosecute if the hospital does not perform any assistance or referral canal as is standard by hospitals in developed countries.

\subsubsection{Local Government}

The difficulty of enforcing human rights due to the state of facilities and infrastructure in hospitals as the main health facilities during the Covid pandemic makes the local government fully responsible for minimizing cases of human rights violations. The Central Government and Local Government have been obliged to conduct synergy to budget and maximize government policies, programs, and activities to improve health services attached to local governments such as Integrated Healthcare Center in the village government. This authority to guarantee human rights in the framework of protection, respect, and fulfillment is also listed in the mandate of the Universal Declaration of Human Rights in 1948, Human Rights Law No. 39 of 1999, and Health Law No. 39 of 2009. The role of local government is very important considering the inaction of the central government in drawing up a strategic plan at the beginning of the covid-19 pandemic. This is instructed in the instruction of the Ministry of Trade number 443.1/2130/SJ which is planned to be submitted to all local governments but delayed because it requires coordination with the ministry of health. (Muhammad Habib Abiyan Dzakwan, 2020: 1)

This shows the inaction and bureaucratic flow of many from the central and local governments are expressly blamed for proactive actions accused by the central government as a place of popularity, troublemakers in the community, and the government within the government. <https://www.beritasatu.com/nasional/604723/dampak-corona-kemdagribelum-keluarkan-imbauan-ke-daerah>.Accessed 30 Juni 2021).

Local governments have great legal political power in conducting pandemic countermeasures in their regional spaces such as determining the status of disaster emergency areas, establishing large-scale social restrictions in each administrative region that are suspected to have great potential in spreading pandemics.

Therefore, to maximize the provision of health services from below during the Covid-19 pandemic the local government has a function in monitoring the readiness of medical personnel in ensuring the protection and uniformity of work, the availability of referral health care facilities to the provincial government, the availability of local government funds in the framework of decentralization or the construction of emergency facilities and infrastructure in each province in Indonesia. (Risyal Hardiyanto, 2020: 43) This aims to avoid the failure of medical personnel in conducting the main toxic treatment of Covid-19 patients resulting in death for health workers. Setting working hours periodically in hospitals, efforts to add referral hospitals in each radius of the region, the fulfillment of physical and material needs for medical personnel, and most importantly the availability of personal protective equipment (PPE) will continuously strengthen the functions and obligations of health workers in Indonesia and even strongly support the fulfillment of human rights for media teams during the Covid-19 pandemic.

Strengthening the capacity of local governments in handling Covid-19 directly also increases the form of minimizing human rights violations during the Covid-19 pandemic. This important role is carried out based on high cases that cause death for the community as patients as well as medical personnel, the gap in public knowledge in each region, and human rights violations, especially the lower class. As also stated in the Government Regulation article 6 No. 47 of 2016 concerning health care facilities and decree of the Head of the National Disaster Management Agency number $13 \mathrm{~A}$ of 2020 all levels of government must support the availability of health equipment in the field, the fulfillment of public and medical rights, transparency of information and policymaking that pays attention to the value of human rights and democracy that can be done through services health from below such as optimization of Integrated Healthcare Center in providing health knowledge, distribution of medical devices, optimization of the functions of community leaders and religious leaders as well as the role of families. (Theresia Louize Pesulima and Yosia Hetharie, 2020: 280)

The legal protection for health workers will directly support the acceptance of hospitals and other health facilities in Indonesia to receive patients in a ready and agile manner. Efforts to foster and supervise health workers have not been fully implemented to weaken the rights and obligations of health workers in carrying out their toxicities in hospitals. The complexity of local government bureaucracy and the distribution of Personal Protective Equipment to all medical personnel on duty in hospitals are expected to no longer be the reason for the obstruction of legal protection and health insurance as well as the safety of the medical team.(Aris Prio Agus Santoso and others, 2020: 275).

\section{Conclusion}

The emergence of the hospital mafia as a form of confusion arising from the case of non-Covid-Covid-19 patients explicitly raises mass concerns for the families of non-Covid-19 patients. The rise of cases that occurred during the Covid19 pandemic include. The emergence of the hospital mafia as a form of confusion arising from the case of non-Covid-Covid19 patients explicitly raises mass concerns for the families of non-Covid-19 patients. The rise of cases that occurred during the Covid-19 pandemic, among others, the refusal of emergency patients that cause death and allegations of covid in non- 
Covid 19 patients that provide social effects in people's lives are very violating human rights. This is very neglected in the glasses of the law and there has been no comprehensive action from law enforcement officials and the human rights commission in reviewing the issue although it is stipulated in the laws and regulations in Indonesia. emergency patients who cause death and allegations of covid in Non-Covid 19 patients who provide social effects in people's lives are very violating human rights. This is very neglected in the glasses of the law and there has been no comprehensive action from law enforcement officials and human rights commissions in reviewing the issue although it is stipulated in the laws and regulations in Indonesia. This is not without reason the lack of health facilities and infrastructure is the main cause although other factors are a problem it has not been legally proven that the hospital mafia wants a huge advantage over the cost per individual that hospitals will receive when treating Covid-19 patients. In addition, the human rights of patients as a society that is entitled to receive health services clash with the right of medical Tenga as labor stipulated in the labor law. Therefore, in solving the problem is not only the role of law enforcement actors such as human rights commissions but also local governments whose positions are very attached to community entities to help hospitals as the vanguard of prevention of human rights violations in obtaining health services as well as the role of families as moral support and cooperation with the government to take care of family members during the Covid-19 pandemic.

\section{References}

i. Adiputra, Putu Anda Tusta, (2020), 'Dampak Pandemi COVID-19 Pada Pelayanan Pasien Kanker Di Rumah Sakit Tersier Di Indonesia: Serial Kasus', JBN (Jurnal Bedah Nasional), $4.1 \quad 29$ https://doi.org/10.24843/jbn.2020.v04.is01.p07

ii. Rembulan, Glisina Dwinoor, Tony Wijaya, Desribeth Palullungan, Kartika Nur Alfina, and Muhammad Qurthuby, 'Kebijakan Pemerintah Mengenai Coronavirus Disease (COVID-19) Di Setiap Provinsi Di Indonesia Berdasarkan Analisis Klaster' (2020), JIEMS (Journal of Industrial Engineering and Management Systems), 13.2 https://doi.org/10.30813/jiems.v13i2.2280

iii. https://nasional.kompas.com/read/2020/12/16/15053601/4-provinsi-ini-alami-kenaikan-tertinggi-kasuscovid-19-usai-libur-panjang. accessed 1 June 2021.

iv. https://properti.kompas.com/read/2020/03/06/200000621/hadapi-virus-corona-ini-6-langkah-yang-wajibdilakukan-rumah-sakit?page=all. accessed 11June 2021.

v. Hidayah, Nur, 'Strategi Rumah Sakit Merespon Pandemi Covid-19 Di Era New Normal Asal Mula Pandemi Covid$19^{\prime}, 2020$

vi. https://www.indozone.id/news/WYsvz6D/kondisi-bayi-sungsang-ibu-hamil-ditolak-rumah-sakit-karena-reaktifcovid-19-ini-akhirnya/read-all. accessed 11 June 2021.

vii. https://regional.kompas.com/read/2020/12/15/16555921/kasus-rumah-sakit-anggap-pasien-positif-covid-19ganjar-laporkan-ke-saya?page=all. accessed 11June 2021

viii. https://nasional.kompas.com/read/2020/10/05/15350241/saat-rumah-sakit-dituding-meng-covid-kanpasien?page $=3$. accessed 21June 2021

ix. https://www.indozone.id/news/jzsQd5p/ditolak-3-rumah-sakit-karena-bukan-covid-19-wanita-ini-saksikansakratul-maut-sang-ayah/read-all. accessed 21 June 2021.

x. Jendri Maliangga, 'Lex et Societatis', I.4 (2013), 5-14'Jurnal Konstituen Merupakan Jurnal Ilmiah Yang Diterbitkan Oleh Fakultas Hukum Tata Pemerintahan, 2020 Institut Pemerintahan Dalam Negeri. Artikel Yang Diterbitkan Jurnal Ini Melalui Proses Penilaian Oleh',

xi. Kementerian Kesehatan Republik Indonesia, Panduan Teknis Pelayanan Rumah Sakit, 2020

xii. Menteri Keuangan Republik Indonesia, 'Satuan Biaya Penggantian Atas Biaya Perawatan Pasien Penyakit Infeksi Emerging Tertentu Bagi Rumah Sakit Yang Menyelenggarakan Pelayanan Coronavirus Disease 2019 (Covid-19)', April, 2020, 2020

xiii. https://www.msn.com/id-id/berita/other/363-tenaga-medis-meninggal-karena-covid-19-ini-3-saran-dariidi/ar-BB1bXoni. accessed 26June 2021

xiv. Kristyawan, Firdaus, and Rinik Eko Kapti, 'Factor Analysis Affecting LOS in Yellow Triage Emergency Room at Bangil Hospital during the COVID-19 Pandemic', (2020), 2.4 604-14

xv. http://zonamahasiswa.id/insiden-rumah-sakit-tolak-pasien-hingga-bayinya-meninggal-sobat-zona-pantaskahnilai-kemanusiaan-diganti-dengan-uang/. accessed 30 June 2021

xvi. Gorontalo, Irwansyah Reza Mohamad Universitas Muhammadiyah, (2019), 'Perlindungan Hukum Atas Hak Mendapatkan Pelayanan Kesehatan Ditinjau Dari Aspek Hak Asasi Manusia', Akademika Jurnal UMGo, 8 116-26

xvii. Prananda, Rahandy Rizky, (2020), 'Batasan Hukum Keterbukaan Data Medis Pasien Pengidap Covid-19', Law, Development \& Justice Review, 3.1 142-68

xviii. Laurensius Arliman S, 'Komnas HAM Sebagai State Auxiliary Bodies Di Dalam Penegakan Hak Asasi Manusia Di Indonesia', Jurnal Bina Mulia Hukum, 2.40 (2017), 54-66 https://doi.org/10.23920/jbmh.v2n1.5

xix. Dzakwan, Muhammad Habib Abiyan, (2020), 'Mapping Local Government Readiness in Handling COVID-19', CSIS Commentaries, 27.April 1-11

xx. https://www.beritasatu.com/nasional/604723/dampak-corona-kemdagri-belum-keluarkan-imbauan-ke-daerah. accessed 30Juni 2021

xxi. Hardiyanto, Risyal, 2020), 'Langkah-Langkah Strategis Untuk Mencegah Pandemi Covid-19 Di Lembaga Pemassyarakatan Indonesia', Jurnal Pendidikan Kesehatan, 9.1 (43-55)

xxii. Pesulima, Theresia Louize, and Yosia Hetharie, 'Perlindungan Hukum Terhadap Keselamatan Kerja Bagi Tenaga Kesehatan Akibat Pandemi Covid-19', Sasi, 26.2 (2020), 280 https://doi.org/10.47268/sasi.v26i2.307 
xxiii. Prio Agus Santoso, Aris, Anita Dwi Septiarini, Safitri Nur Rohmah, and Ary Rachman Haryadi, 'Perlindungan Hukum Tenaga Kesehatan Dalam Gugus Tugas Percepatan Penanganan Covid-19 Ditinjau Dari Sudut Pandang Hukum Administrasi Negara', Prosiding HUBISINTEK, 1 (2020), 275-275

<http://ojs.udb.ac.id/index.php/HUBISINTEK/article/view/1006> 